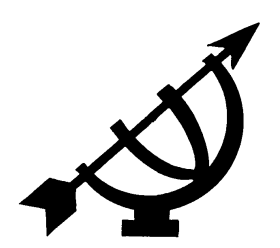

\title{
Die uitdagings van MIV/VIGS-opvoeding vir die "gewone" klas- en vakonderwyser: 'n prinsipiële besinning
}

\author{
J. Moodley, G. Urbani, A. van der Merwe \\ Fakulteit Opvoedkunde \\ Universiteit van Zululand, Umlazi-kampus \\ AMANZIMTOTI \\ J.L. van der Walt \\ Fakulteit Opvoedingswetenskappe \\ Potchefstroomkampus \\ Noordwes-Universiteit \\ POTCHEFSTROOM \\ E-pos: jlvdwalt@intekom.co.za
}

\begin{abstract}
The challenges of HIV/AIDS education for the "ordinary" class and subject teacher: A principial reflection

HIV/AIDS has become a wide-spread epidemic. It has already claimed thousands of lives and many others are infected daily. HIVIAIDS education forms an important facet in the struggle against the disease, also in schools where 'ordinary' teachers (i.e. not professional AIDS practitioners) find themselves having to deal with classes of students in which learners infected by HIV or suffering from full-blown AIDS might be present. HIVIAIDS education confronts these teachers with several challenges. Feedback from an empirical survey in a province of South Africa where HIVIAIDS has assumed rampant proportions revealed that, while these 'ordinary' teachers were quite prepared to become involved in the struggle against HIVIAIDS, they did not see themselves as adequately equipped and prepared for the task. A number of recommendations are made to deal with this shortcoming in their training.
\end{abstract}


Opsomming

Die uitdagings van MIV/VIGS-opvoeding vir die "gewone" klas- en vakonderwyser: 'n prinsipiële besinning

MIVIVIGS het 'n wydverspreide epidemie geword. Dit het reeds duisende lewens geëis, en daagliks word nog meer mense aangetas. MIVIVIGS-opvoeding vorm 'n belangrike deel van die stryd teen die siektetoestand, ook in die skole, waar 'gewone' onderwysers (dit is nie professionele VIGS-praktisyns nie) te doen kry met klasse vol leerlinge waarvan sommige deur MIV geïnfekteer is en ander alreeds voluit aan VIGS ly. MIVIVIGS-opvoeding konfronteer hierdie onderwysers met verskeie uitdagings. Terugvoering uit 'n empiriese opname in 'n provinsie van Suid-Afrika waar MIVIVIGS hoogty vier, het aan die lig gebring dat, hoewel hierdie 'gewone' onderwysers bereid was om deel te neem aan die stryd teen MIVIVIGS, hulle hulself nie as voldoende toegerus en voorberei vir die taak ag nie. 'n Aantal aanbevelings word gemaak om hierdie tekortkoming in hulle opleiding uit die weg te ruim.

\section{Doel van die besinning}

MIV/VIGS (Menslike Immuniteitsgebrek-virus/Verworwe immuniteitsgebreksindroom, ook in die omgang bekend as "HIV/AIDS") is reeds sedert 1983 'n werklikheid in die Suid-Afrikaanse samelewing, onder meer in ouerhuise en skole. Omdat daar heelwat meningsverskil en kontroversie bestaan oor die werklike oorsake daarvan, was daar in Suid-Afrika tot onlangs nog nie 'n eenduidige en omvattende program om hierdie gevaarlike epidemie die hoof te bied en uit die weg te probeer ruim nie.1 Daar is in tersaaklike vakliteratuur 'n deurlopende gesprek aan die gang oor wat die oorsake van die siektetoestand is, wat die gevolge daarvan is, hoe dit bestry kan word, en wat die uitwerking daarvan op die opvoeding, onderwys (vgl. Moodley, 2002), die ekonomie en die samelewing in die algemeen is. Hierdie artikel is bedoel as 'n verdere bydrae tot hierdie gesprek, veral ten aansien van die situasie in Suid-Afrika. Die bydrae wat met hierdie artikel tot die gesprek gemaak wil word, is om onder meer verslag te lewer oor die toegerustheid van "gewone" klas- en vakonderwysers (voortaan: die onderwyser) in 'n

1 Die UNAids-program bekend as Greater involvement of people living with HIVIAIDS (GIPA) is al sedert 1983 in werking, maar het eers in 1997 in SuidAfrika grondgevat. Op daardie stadium het 11 persone daarby aangesluit, waarvan twee voor 2001 oorlede is. Sedert die Paryse VIGS-beraad van 1994 het 42 lande by die GIPA-program aangesluit. Die doel van die GIPA-program is om 'n effektiewe en etiese respons tot die epidemie te bied, met ander woorde om 'n menslike en persoonlike gesig aan MIV/VIGS te gee (Haffajee, 2001:8). 
bepaalde deel van die land (te wete Kwazulu-Natal) om die uitdagings van MIV/VIGS-opvoeding die hoof te bied en die saak ook prinsipieel vanuit 'n reformatoriese denkraamwerk te bekyk.

Die besinning is soos volg gestruktureer: Ten eerste word verslag gedoen oor die voorkoms van die siektetoestand wêreldwyd maar veral in Suid-Afrika. Daarna word besin oor die besondere uitdagings wat MIV/VIGS(-opvoeding) aan die opvoeder (met name die onderwyser) stel. Dit word gevolg deur 'n verslag oor 'n ondersoek wat uitgevoer is om vas te stel of onderwysers in 'n deel van die land waar die MIV/VIGS-epidemie hoogty vier (KwazuluNatal), hulself as gereed beskou om hierdie uitdagings die hoof te bied. Enkele aanbevelings word gemaak ten opsigte van die toegerustheid van onderwysers om inderdaad die uitdagings van MIV/VIGS-opvoeding in die praktyk te behartig. Soos algaande sal blyk, word besin vanuit 'n reformatoriese denkraamwerk. "Reformatoriese denkraamwerk" verwys na 'n benadering wat ontwikkel is in die lig van die Christelike geloof as die basiese grondmotief (Fowler, 1987:10). Waar moontlik word die lig van die Bybel, die Skrifwoord van God, op die problematiek gewerp in die oortuiging dat die hantering van die MIV/VIGS-probleem moet plaasvind "in believing response to the Word of God" (Fowler, Van Brummelen \& Van Dyk, 1990:14 e.v.). In 'n sekere sin vind hierdie besinning dus aansluiting by die ondersoek van Achineku en Map International (1999). Hulle ondersoek het hoofsaaklik gefokus op die verantwoordelikheid van die Christen in die algemeen, en die kerk in die besonder, in die hantering van die MIV/VIGS-probleem. In hierdie artikel is die fokus meer op opvoedende onderwys en veral op onderwysers se toegerustheid en gereedheid om die probleem die hoof te bied.

\section{Die werklikheid van MIV/VIGS in die skoolomgewing in Suid-Afrika}

Die eerste berig in die algemene pers oor MIV/VIGS is in Julie 1981 in die New York Times gepubliseer. Dit het verwys na die US Center for Disease Control se verslag oor 'n infeksie wat slegs gay mans tref. Ondersoeke het aan die lig gebring dat die siekes simptome toon wat verband hou met 'n verswakte immuunstelsel, soos wat byvoorbeeld by kankerlyers opgemerk is. Dit was die begin van ' $n$ bewustheid oor 'n siektetoestand wat die verbeelding aangegryp het soos min ander. Teen 1986 het dié siektetoestand ook ander mense as gay mans getref en dit was besig om vinnig te versprei. Omdat die toestand deur seksuele omgang versprei is en omdat dit indertyd onder gay mans voorgekom het, was die VSA-regering aanvanklik 
traag om op te tree ${ }^{2}$ (Taitz, 2001:21). Intussen het die siekte wêreldwyd versprei.

Volgens 'n verslag deur die Verenigde Nasies se bevolkingsfonds getitel Die status van die wêreld se bevolking (2003) word daar wêreldwyd daagliks ongeveer 6000 mense tussen die ouderdomme van 15 en 24 met MIV geïnfekteer. Dit is die helfte van alle nuwe infeksies. Die meeste van diegene wat aangetas word, is vroue uit die ontwikkelende wêreld (twee uit elke drie infeksies). Ander bevindings is dat baie van die nuwe geïnfekteerdes nie weet hoe hulle geïnfekteer geraak het nie en hoe hulle hulle daarteen kon beskerm het nie. Ander is bloot nie by magte om aan te dring op veilige seks nie (Reuters \& BBC News, 2003). Volgens die VN en die Wêreldgesondheidorganisasie (WGO) se skattings is ongeveer 29,4 miljoen Afrikane geïnfekteer. 3 Volgens die WGO is die getal mense wat met MIV/VIGS moet saamleef aan die toeneem, veral in sub-Sahara-Afrika, met suidelike Afrika as die kerngebied (Blomfield, 2004:3). In 2001 het ongeveer 2,4 miljoen mense in Afrika gesterf, en was ongeveer 30 miljoen deur MIV (voorloper van VIGS) geïnfekteer4,5 (Anon., 2002:7). Volgens syfers bekendgestel in Rapport (1 Desember 2002:32) was daar in Julie 2002 wêreldwyd 42 miljoen mense wat MIV/VIGS het (teenoor 40 miljoen die vorige jaar). Van hierdie groep was 3,2 miljoen kinders jonger as vyftien jaar. In Afrika suid van die Sahara was daar, soos reeds opgemerk is, in 2002 altesaam 29,4 miljoen 6 wat MIV-positief was, en 'n

$2 \quad$ Na raming is ongeveer 950000 mense in die VSA MIV-positief. Hoewel die syfer sedert 1993 taamlik konstant gebly het, het dit in 2003 weer met 2,2\% toegeneem. Weens verbeterde medikasie het die sterftes egter in totaal met $6 \%$ per jaar afgeneem (Lamprecht, 2003).

3 In die lig van noukeuriger navorsing onlangs in Kenia ('n meer verteenwoordigende steekproef) is hierdie syfer oordrewe. Slegs ongeveer 22 miljoen mense in Afrika is geïnfekteer. Op grond van hierdie noukeuriger navorsing het die UNAids-program sy raming van infeksies vir 2003 aangepas vanaf 22-35 miljoen tot 25-28,2 miljoen (Blomfield, 2004:3).

$4 \quad$ Hierdie syfer stem ooreen met die oordrewe syfer waarna in voetnoot 3 verwys is.

5 Die Soul City: Institute for Health sê van MIV: “... a study in the US of 8000 participants, found that people with HIV were 1100 times more likely to develop a disease associated with AIDS than someone without HIV. In medical science this is considered an extremely high association between a cause and effect, ..." (Soul City, 2003?:2).

$6 \quad$ 'n Meer korrekte syfer is tussen 25 en 28 miljoen. 
verdere 3,5 miljoen sou volgens projeksies in daardie jaar nog geïnfekteer word. Wêreldwyd het 3,1 miljoen mense aan die siekte gesterf, waarvan 610000 kinders jonger as vyftien. Van hierdie totaal was 2,4 miljoen in Afrika suid van die Sahara.

Volgens sekere kenners bestaan daar 'n sterk moontlikheid dat die swaartepunt van die epidemie in die volgende geslag van Afrika suid van die Sahara na Eurasië (Rusland, Indië en China) kan verskuif. Volgens die mees pessimistiese scenario kan daar tussen 2000 en 2025 soveel as 155 miljoen mense aan die siektetoestand in daardie streek (Eurasië) beswyk. Die infeksiesyfer staan in Indië alreeds iewers tussen 5 en 8 miljoen. Die verwagting is dat ongeveer 10 miljoen Chinese teen 2010 MIV-positief kan wees. In Rusland was daar al in 2002 ongeveer eenmiljoen mense wat MIV-positief was (Du Toit, 2002:16).

MIV/VIGS is die eerste keer in Suid-Afrika gemerk in die vroeë tagtigerjare. Dit was destyds biologies verbind aan die epidemie in die VSA en Europa en het hoofsaaklik homoseksuele mans en dwelmslawe wat inspuitnaalde gebruik het, getref. Hierdie eerste vlaag is gevolg deur ' $n$ tweede laat in die laat tagtigerjare, een wat biologies gekoppel was aan VIGS uit sentraal- en oos-Afrika. Tot ongeveer die negentigerjare, toe anti-retrovirale terapie beskikbaar geraak het in die meer ontwikkelde (ryker, noordelike) lande, was VIGS 'n doodsvonnis vir die geïnfekteerde. Aktiviste in die noordelike lande het daarin geslaag om veldtogte te loods waardeur die terapie meer vrylik en bekostigbaar beskikbaar gestel is. Op grond van hierdie optredes in die meer ontwikkelde lande het byvoorbeeld die Treatment Action Campaign (TAC) in Suid-Afrika ook veldtogte van stapel gestuur om die terapie meer bekostigbaar en vryliker beskikbaar te stel. Hierdie pogings was aanvanklik nie geslaagd nie, aangesien die regering (met name die Departement van Gesondheid) nie oortuig was dat die oorsake reg gediagnoseer was en dat die terapie die korrekte sou wees nie (Schneider, 2001:18-21). In 2003 is anti-retrovirale terapie egter goedgekeur en wel teen bekostigbare pryse.

Meer as 120 onafhanklike ondersoeke in Suider-Afrika het aan die lig gebring dat meer as $18 \%$ van alle werknemers in die streek al met MIV/VIGS saamleef. Na skatting is ongeveer $90 \%$ van alle geïnfekteerdes nog in die "gesonde" asimptomatiese pre-VIGSstadium (Jelley, 2003:8). Volgens 'n ondersoek deur die SA Medical Research Council was die siekte egter al in 2000 verantwoordelik vir ongeveer 39\% van alle "voortydige" sterfgevalle. Na raming sterf daagliks ongeveer 600 mense (waaronder 100 kinders) aan die 
siekte7 (De Villiers \& Pienaar, 2003). Die studie het ook aan die lig gebring dat, indien daar nie betyds ingegryp word nie, die getal "voortydige" sterfgevalle teen 2010 sal verdubbel. Die sogenaamde disease burden van Suid-Afrika, so meen die navorsers, het vinnig verander as gevolg van die koms van MIV/VIGS. Volgens hulle studie is MIV/VIGS nou die hoofoorsaak van sterftes in Suid-Afrika, selfs al word dit vergelyk met 'n kombinasie van ander siektes. $\mathrm{Na}$ raming veroorsaak MIV/VIGS 'n verlies van 39\% aan lewensjare (by vroulike persone $47 \%$ en by manlike persone $33 \%$ ). Die voorkoms van die siekte is hoër onder vroulikes en ook op 'n jonger leeftyd. Die voorkoms van hierdie siekte (asook ander doodsoorsake soos tuberkulose, moord en verkeersbotsings) is ook buitengewoon hoog in vergelyking met ander streke in die wêreld. MIV/VIGS skep nie slegs op sigself 'n probleem nie, maar verhoog ook die disease burden in geval van ander siektes soos cholera en tuberkulose (Bradshaw, 2003). 'n UNAIDS-studie in 2002 het aan die lig gebring dat teen 2005 nagenoeg 11\% van alle Suid-Afrikaanse werkers aan VIGS-verwante oorsake sal sterf en teen 2020 sal die syfer na verwagting tot nagenoeg $25 \%$ styg 8 (Willemse, 2003).

Wat die onderwys betref, is daar in 'n ondersoek (waarvan die uitslag in 2001 deur die Minister van Onderwys verwerp is) bevind dat VIGS die grootste moordenaar van onderwysers is. So veel as $20 \%$ van die onderwysers in Kwazulu-Natal en so veel as $16 \%$ in die ander agt provinsies is reeds MIV-positief. Tussen $7 \%$ en $8 \%$ van alle skoolhoofde en departementshoofde is reeds MIV-positief (Monare, 2003:21). Onder andere weens hierdie probleem betaal die Oos-Kaapse onderwysdepartement daagliks ongeveer R5,3

7 Volgens sommige ander navorsers is hierdie sterftesyfer oordrewe, en kan toegeskryf word aan pogings deur aktiviste om die regering tot optrede te dwing, byvoorbeeld om retrovirale middels beskikbaar te stel. Volgens die berekeninge van dr. Stuart Dwyer, 'n distriksgeneesheer van Grahamstad, was die syfer vir 2001 byvoorbeeld $765 \%$ hoër as die werklike sterftesyfer deur Statistics SA aangeteken. Volgens die UNAIDS webbladsy was 360000 sterftes geprojekteer vir 2001; die ASSA-model het 271000 voorspel. Die werklike sterftesyfer aangeteken deur SA Statistics was egter slegs 47000 (Rank, 2004:1). Noudat die regering $\mathrm{R} 2$ miljard beskikbaar gestel het vir die anti-retrovirale program, hoor 'n mens nie meer van die aktiviste nie, het dr. Dwyer gesê. Dieselfde tendens kan elders bespeur word. In Kenia is aanvanklik gemeen dat ongeveer 3 miljoen mense geïnfekteer was. Onlangse ondersoeke het getoon dat slegs een miljoen geïnfekteer is. Dieselde kan gesê word van die situasie in Mali en Zambië.

8 In Botswana, Mosambiek en Zimbabwe wissel die syfers tussen 9\% en 31\% (Willemse, 2003). 
miljoen uit aan die nagenoeg 16000 onderwysers wat om onverklaarbare redes vir lang tye van die skool af wegbly (Louw, 2003). Verder is bevind dat een uit elke vier voorgraadse studente en een uit elke agt nagraadse studente aan hoëronderwysinstellings anders as technikons MIV-positief is. Een uit elke vyf technikonstudente was reeds MIV-positief. (In Julie 2003 is aangekondig dat 'n nuwe studie oor MIV/VIGS onder onderwysers gedoen sal word; vgl. Monare, 2003:21).

Volgens 'n Metropolitan Life-studie (2000, soos gerapporteer deur George, 2001:11), was daar in 1999 ongeveer 153000 VIGSweeskinders in Suid-Afrika en die getal sal teen 2005 aangroei tot I miljoen, en tot 2 miljoen in 2010.

\section{Standpunte oor die voorkoming en bestryding van die epidemie}

Daar is in wese twee breë benaderingwyses as dit by die voorkoming en bestryding van MIV/VIGS kom. Aan die een kant is daar wêreldwyd 'n groep wat getipeer kan word as die "VIGS-wêreld". Hierdie term snoer wetenskaplikes, aktiviste, plaaslike en internasionale nie-regeringsorganisasies (NRO's) en agentskappe saam in 'n globale beweging. Hulle neig om die VIGS-stryd te koppel aan die ongelykhede tussen die noordelike ryk lande en die suidelike armer lande, aan onbillike handelspraktyke en die mag van multinasionale medisyne-industrieë. In Suid-Afrika bevind byvoorbeeld die Treatment Action Campain (TAC), die primêre-sorgpraktisyns en die openbare gesondheidswetenskaplikes hulle in hierdie groepering.

Aan die ander kant is die Suid-Afrikaanse regering, in die vorm van die Departemente van Gesondheid en Onderwys. Hierdie groepering beskik oor die geld vir die programme, maar hulle het ook hulle eie siening oor die hantering van die epidemie (Schneider, $2001: 18)$. Onderwysprogramme vorm 'n belangrike onderdeel van die owerheidstrategie om die epidemie die hoof te bied. Omdat die hoogste voorkoms van die siekte in die naskoolse ouderdomsgroep van 18 tot 35 jaar is, is dit belangrik om toekomstige volwassenes reeds op skole toe te rus om MIV/VIGS die hoof te kan bied. MIV/VIGS is inderdaad in skole ook ' $n$ probleem; vandaar dat in 2002 sowat R300 miljoen uit die lewensvaardighedeprogram aan MIV/VIGS-opvoeding (-voorligting) bestee is. Hierdie program sluit aspekte soos opleiding, die aanskaffing van leermateriaal, bekendmakingsveldtogte, riglyne vir portuurgroepe en voorkomingsmaatreëls in (Jongbloed, 2002). 


\section{Benadering tot die MIV/VIGS-probleem vanuit reformatoriese perspektief}

Die Christen-opvoeder (-onderwyser), soos enige ander mens, stel as 'n reël vier lewensbeskoulike vrae: (1) Wie is ek en waar kom ek vandaan? (2) Waar bevind ek my? (3) Wat het skeefgeloop met die situasie waarin ek my bevind? (4) Hoe kan hierdie situasie weer reggestel word? (Middleton \& Walsh, 1995:11; Fernhout, 1997:84). Die eerste vraag het te doen met die mensbeskouing wat 'n mens huldig, die tweede met 'n mens se werklikheidsbeskouing, die derde met 'n mens se siening van sonde en kwaad, en die vierde met herstel uit die toestand van gebrokenheid en gevallenheid.

In terme van die MIV/VIGS-gesprek sou 'n mens na aanleiding van die eerste vraag soos volg kon antwoord: Elke mens, dus ook die MIV/VIGS-geïnfekteerde, is deur God geskep, is beeld van God en die kroon van die skepping. Elkeen, ook die MIV/VIGS-geïnfekteerde, is daarom die eerbied van sy medemens waardig. Daar mag nie teen enige persoon gediskrimineer word nie; die MIV/VIGSgeïnfekteerde en die siektetoestand waaraan gely word, mag nie gestigmatiseer word nie. Die geïnfekteerde mag nie verdryf, geïsoleer, verstoot of geminag word nie. Soos elke mens is die geïnfekteerde geregtig op die erkenning van menswaardigheid. Die voorwaarde vir die erkenning van menswaardigheid sluit ook in dat die MIV/VIGS-geïnfekteerde liefdevol en met medelye versorg behoort te word tot aan die einde van die lewe wat hom of haar gegun word.

In terme van die MIV/VIGS-gesprek sou 'n mens soos volg kon antwoord op die tweede vraag: Elke mens, ook die MIV/VIGSgeïnfekteerde, bevind hom- of haarself in God se skepping, waar hy of sy geroep is om die skepping te bewoon, te bewaak en te bewerk. Elkeen wat daartoe in staat is, ook die geïnfekteerde, moet toegelaat word om hierdie roeping na te kom vir sover dit vir hom of haar moontlik is, om sy of haar rentmeesterskap en dissipelskap in die skepping uit te voer. Elkeen is ook geregtig op die benutting van die bronne wat die skepping bied. Dit sluit, in die geval van die MIV/VIGS-geïnfekteerde ook die benutting van enige anti-retrovirale middele of ander geneesmiddels in. Alles behoort ook in die werk gestel te word om die oorsake van die siektetoestand te ontdek, om dit te bestry, om die nodige middele vir die bestryding daarvan te ontwikkel (as deel van die mens se kultuurtaak). In beginsel behoort dit nie vir MIV/VIGS-geïnfekteerdes nodig te wees om statistieke te oordryf of oor te gaan tot aktivisme voordat die nodige aandag aan hulle toestand gegee word nie. 
In terme van die MIV/VIGS-debat het die derde vraag te doen met die sonde en kwaad wat in hierdie wêreld ingekom het weens die ongehoorsaamheid van die mens aan God. Weens ongehoorsaamheid van die mens het die mensdom in sonde geval, bevind die mens hom in 'n gebroke en gevalle toestand. Die MIV/VIGSepidemie, soos siekte en dood in die algemeen, is maar net nog een van die tekens van die gevallenheid en gebrokenheid van die mensdom en die skepping. Weens die ongehoorsaamheid van die mens doen sommige mense hierdie siektetoestand op, soms onbedoeld en per ongeluk, soms doelbewus, soos wanneer hulle seksueel losbandig lewe, onveilige seks beoefen, nie behoorlik ingelig is oor hoe 'n mens die MIV/VIGS-toestand kan opdoen nie of nie toegang het tot die nodige middele om dit te bestry nie. In die lig van die mensbeskouing wat hier gehuldig word (vraag 1), moet die medemens van die MIV/VIGS-geïnfekteerde die siektetoestand haat omdat dit die gevolg is van die sondetoestand en gebrokenheid waarin die mens(dom) verkeer, maar die mens wat aan die siekte ly, moet liefgehê en gekoester word. Dit is wat die tweede gedeelte van die sentrale liefdesgebod (jy moet jou naaste liefhê soos jouself) eis.

In terme van die MIV/VIGS-debat impliseer die vierde vraag dat daar gesoek moet word na herstel. Die Bybel leer dat Jesus Christus, die Seun van God, aan die kruis gesterf het om vir die sondes van hierdie wêreld en vir die mense daarop te betaal en om daardeur die mens en die wêreld met God te versoen, om die verhouding met Hom te herstel. Hierdie versoening was eenmalig, en gelowiges leef kragtig vanuit hierdie wete. Intussen bevind hulle hulle egter in 'n situasie waarin die herstel nog nie volkome deurgebreek het nie, en kry hulle dus te doen met verskynsels soos MIV/VIGS waarmee geworstel word. As deel van die herstelproses moet alle siektes in hierdie bedeling met krag voorkom en bestry word, moet die siekes gehelp word om die gevolge van die siektes te kan dra, moet hulle liefgehê en gekoester word met die liefde van Jesus Christus. Ook moet geglo word dat die dood, as dit intree, die deurgang na die ewige lewe in die teenwoordigheid van God is. MIV/VIGS moet soos enige ander siekte, byvoorbeeld soos kanker, benader word: die geïnfekteerde moet bygestaan word terwyl hy of sy besig is om deur hierdie tydelike bestaan te gaan. Die mens se aardse bestaan is ' $n$ tydelike tentwoning; die mens is soos 'n bywoner in hierdie bedeling. Soos die tentwoning afgetakel word, word die perspektief op die ewige woning in die eie land van die toekoms vir die mens duideliker. Die VIGS-geïnfekteerde moet gehelp word om hierdie perspektief te bly behou. 


\section{Opvoedingsperspektief}

Die antwoorde wat 'n mens op die vier lewensbeskoulike vrae gee, het regstreekse implikasies vir die opvoeding en onderwys. Opvoeding is in wese ' $n$ proses ${ }^{9}$ van toerusting. Die opvoeder (met name die onderwyser) het die taak om die opvoedeling (met name die leerder) op tweërlei wyse toe te rus: sodat hy of sy enersyds verstaan hoe die VIGS-siektetoestand ontstaan en hoe 'n mens dit kan vermy, en sodat hy of sy sal weet hoe om om te gaan met mense wat wel daaraan ly. Opvoeding is ook 'n proses van ontplooiing: ontplooiing van die potensiaal van die kind, en ontplooiing van die werklikheid vir die opvoedeling. Opvoeding is verder 'n proses van dissipelvorming: die leerder moet verstaan wat dit beteken om die Woord van God te hoor en dit ook te doen. Seksueel losbandige gedrag deur die opvoeder is allermins 'n goeie voorbeeld van dissipelvorming. Dissipelvorming en -skap behels ook diens en sorg (versorging): verwerping van 'n VIGS-geïnfekteerde is nie-nakoming van hierdie norm. Opvoeding is voorts 'n proses van in staatstelling: dit rus die opvoedeling toe om vir hom of haar ' $n$ pad deur die lewe te vind, 'n pad waarop onder meer die gevare van siektetoestande soos MIV/VIGS vermy en bestry kan word. Opvoeding is ook 'n proses van modellering: deur versigtig invloede op die opvoedeling te laat uitgaan word die leerder lewensbeskoulik en ook vir die uitdagings van die lewe gevorm (Fernhout, 1997:77 e.v.). Deur hierdie invloed leer die opvoedeling byvoorbeeld wat die antwoorde op die vier lewensbeskoulike vrae is vanuit 'n reformatoriese denkraamwerk.

\section{Enkele spesifieke vaardighede waaroor die onderwyser behoort te beskik om die MIV/VIGS- epidemie die hoof te kan bied}

Volgens sowel die Grondwet van die Republiek van Suid-Afrika (1996, hoofstuk 2) as die Nasionale Skolewet (1996) (vgl. Republiek van Suid-Afrika, 1996) mag daar teen geen persoon gediskrimineer word op grond van byvoorbeeld siektetoestand nie10. Daar kan dus

9 "Proses" moet hier nie verstaan word as 'n vanselflopende meganistiese prosedure nie. Dit dui in die konteks van 'n reformatoriese opvoedingsbeskouing op reekse ingewikkelde inter- en intramenslike toerustingshandelinge. Sommige opvoedkundiges verkies derhalwe om eerder van "handelinge" of "gebeure" te praat.

10 In enkele gevalle is leerders egter toegang tot skole of bewaarsentrums geweier. Die hof het die verweer van die betrokke skool aanvaar dat dit nie gereed 
van die vertrekpunt uitgegaan word dat MIV/VIGS-geïnfekteerdes hulle in die reël in die hoofstroom van die onderwys bevind. Hulle is met ander woorde teenwoordig in die gewone klasgroepe wat deur gewone onderwysers (nie spesialis-beraders of -VIGS-opvoeders nie) behartig moet word. Hierdie toedrag van sake bring mee dat die onderwyser oor 'n aantal spesifieke (bykomende) vaardighede moet beskik om te kan voorsien in die behoeftes van die MIV/VIGSgeïnfekteerde.11 Die spesifieke bykomende vaardighede waaroor die onderwyser behoort te beskik, sluit die volgende in ${ }^{12}$ :

\subsection{Bekendheid met beleidsaspekte}

Die onderwyser behoort behoorlik ingelig te wees oor die nasionale en provinsiale onderwysdepartemente se doelwitte met die hantering en bestryding van die epidemie. Kennis moet byvoorbeeld geneem word van die inhoud van beleidsdokumente van die nasionale departement soos die National Policy on HIV/AIDS for learners in Public Schools (Departement van Onderwys, 1996) en die National Policy on HIVIAIDS for learners and educators in public schools and students and educators in further education and training institutions (1999). Op grond van blootstelling aan dokumente soos hierdie sal die onderwyser bewus wees van die feit dat die onderwysdepartemente (nasionaal sowel as provinsiaal) hulle ten doel gestel het om dringend en doelgerig te werk aan die MIV/VIGSprobleem, ook in die konteks van die skole. Deur dit te doen is die departemente oortuig daarvan dat die verskillende gemeenskappe

was om in die spesiale behoeftes van 'n persoon wat aan volledig-ontwikkelde VIGS ly, te voorsien nie (Mkhwanazi, 2003:5).

11 Weens die leerder se reg op privaatheid is dit nie altyd vir die onderwyser moontlik om te weet wie nog slegs in die MIV-stadium verkeer en wie al volledig aan VIGS ly nie. Die onderwyser moet dus van die standpunt uitgaan dat daar in enige besondere klasgroep wel leerders teenwoordig kan wees wat aan MIV/VIGS ly. Hierdie bewus wees van die probleem sal die totale instelling en gesindheid van die onderwyser teenoor sy leerders bepaal.

12 Die onderwyser moet oor meer vaardighede beskik as wat binne die beperkings van 'n tydskrifartikel bespreek kan word. Vaardighede soos die vorming van verhoudinge, die stimulering van natuurlike nuuskierigheid, die vorming van karakter, houding en gesindheid, die bestuur van die MIV/VIGS-program in die klaskamer, die hantering van dissipline ten aansien van die VIGS-lyer, die onderwyser se fasiliteringsrol, pastorale sorg en leiding tot verantwoordelike burgerskap, die benutting van menslike en fisiese hulpbronne, die medewerking met kollegas, leierskap, kulturele en godsdienstige sensitiwiteit, die praktiese implikasies van die verskillende ingrepe, die ontwerp van onderrigmedia, om maar slegs enkele verdere vaardighede te noem, kan nie aan die orde gestel word nie. 
waartoe die leerders behoort, baie toekomstige ellende gespaar sal kan word. Die onderwyser sal ook uit die dokumente agterkom dat die departemente vasberade is om al die grondwetlike regte van die MIV/VIGS-geïnfekteerde te eerbiedig en te beskerm. Blootstelling aan hierdie beleidsdokumente sal vir die onderwyser onderstreep dat hy of sy voor 'n omvangryke en belangrike taak staan wat die bestryding van MIV/VIGS en die hantering van MIV/VIGS-geïnfekteerdes betref.

\subsection{Die vaardigheid om gedrag ten goede te verander}

Die onderwyser behoort ook deeglik ingelig te wees oor wat gedragsverandering behels. Die verspreiding van MIV/VIGS is in wese afhanklik van hoe mense hulle gedra. Volgens Connor en Kingman (1988:1) lê die "welslae" van MIV/VIGS juis in die feit dat dit die mens tref "during the most intimate and compulsive of human activities - sex". Dit is dus noodsaaklik vir die onderwyser om te weet hoe om die leerders te lei en toe te rus om hulle seksuele gedrag te verander (onthouding, veilige seks) (Turner, Miller \& Moses, 1989:261). Onderwysers moet ingelig wees: hulle moet die probleem ken (oor al die nodige kennis beskik), bereid wees om op te tree om die probleem te voorkom, oor die vaardighede beskik om die probleem te hanteer as dit wel opduik. Die onderwyser moet nie onnodig "bang wees" vir die probleem nie, en moet veral nie teen die MIV/VIGS-geïnfekteerdes diskrimineer nie. In sy/haar interaksie met die leerders moet die onderwyser die leerders onder andere help om die risiko van losbandige seksuele gedrag te verstaan; die leerders moet ingelig word met kennis van die epidemie en die verspreiding daarvan (onder meer deur gebruik te maak van toepaslike media); die leerders moet gehelp word om te verstaan hoe hulle die probleem kan vermy of voorkom deur hulle eie (geslagtelike) gedrag te verander. In hierdie proses van leidinggewing moet die onderwyser spesifiek wees (pertinent praat oor die soort gedrag wat moet verander); struikelblokke in die weg van gedragsverandering moet uitgewys word en waar moontlik verwyder word (swak kommunikasie tussen byvoorbeeld opvoeders en leerders is so 'n struikelblok) (Van Dyk, 1999:126).

\subsection{Vaardighede vereis deur multikulturele onderwys}

Die onderwyser behoort verkieslik ook oor die vaardighede van multikulturele onderwys te beskik. Die benadering wat gevolg word in die hantering en bestryding van die probleem, moet kultureel aangepas wees by die betrokke individue en groepe leerders. Die onderwyser moet byvoorbeeld in staat wees om in hulle moedertaal 
met die leerders te kommunikeer. Wanneer 'n woord nie in 'n bepaalde taal bestaan nie (soos: kondoom, virus, immuniteit wat byvoorbeeld nie normaalweg in swart tale bestaan nie) moet toepaslike alternatiewe en analogieë gebruik kan word (Van Dyk, 1991:131). Dieselfde geld vir woorde wat verskillende konnotasies in verskillende tale het. "Promiskuïteit" en "prostitusie" het byvoorbeeld nie dieselfde betekenis in alle kultuurkontekste nie. In sommige kulture is dit heeltemal aanvaarbaar vir 'n persoon om meer as een seksmaat te hê.

\subsection{Die vaardigheid om MIV/VIGS-opvoeding te kan behartig as deel van 'n omvattende gesondheidsplan}

Die onderwyser behoort bewus te wees van die feit dat die bestryding van MIV/VIGS deel vorm van 'n omvattende gesondheidsprogram en dat dit nie geïsoleerd daarvan kan staan nie. Die onderwyser moet dus in staat wees om die liggaamlike gesondheid van die leerders te bevorder, maar daarnaas ook hulle geestelike gesondheid. Leerders wat self-geaktualiseerd is, wie se algemene lewensgehalte goed is, wat die regte besluite kan neem, wat verantwoordelikheid geleer het, wat oor die nodige copingvaardighede beskik, sal beter in staat wees om die gevare van MIV/VIGS te ontwyk. Elke onderwyser behoort dus in staat te wees om by te dra tot die vorming van lewensvaardighede by die leerders. Sulke vaardighede sluit in: assertiwiteit, 'n sterk geloof in die eie vermoëns, 'n positiewe selfkonsep, en self-bewussyn (Vrey, 1993: 167; Kruger, 1998:8). Verdere vaardighede is die volgende: die vermoë om keuses te maak en verantwoordelik daarvoor te wees; die vermoë om portuurgroepdruk te weerstaan; verantwoordelikheid vir die self en die ander; probleemoplossing. Leerders moet ook leer om sosiaal en emosioneel te ontwikkel. VIGS-geïnfekteerdes moet gehelp word om te verstaan dat hulle nie minderwaardig is nie, dat hulle nie nodig het om te ly onder bedruktheid, kommer en woede nie (Louw, Edwards \& Orr, 2001:23). Die opvoeder moet VIGSgeïnfekteerdes nie anders hanteer as ander leerders nie. Hulle gevoel dat hulle "anders" is as ander leerders moet nie versterk word nie, aangesien dit nadelig is vir hulle opvatting van self-waarde en kan lei tot ontoereikendsgevoelens.

\subsection{Die vaardigheid om te versorg en te ondersteun}

Hoewel die onderwyser in die algemeen 'n versorgende en ondersteunende rol vir alle leerders moet vervul, is hierdie rol des te meer belangrik vir die MIV/VIGS-geïnfekteerde. Een manier om dit te doen is om enige bedreigende boodskappe wat die leerder mag 
bereik te voorkom, aangesien dit die VIGS-geïnfekteerde se angs mag verhoog (Turner, Miller \& Moses, 1989:266). Die lyer moet ook gehelp word om hierdie soort boodskappe te kan hanteer indien hulle hom of haar wel bereik. Oor die algemeen moet gesorg word dat die angsvlak van die leerder laag bly aangesien onderrig en leer baie moeilik is wanneer die leerder baie angstig is. Leerders wat nog nie aan MIV/VIGS ly nie, se gedrag moet verander word deur gebruik te maak van positiewe tegnieke en nie van angs- en vreesboodskappe nie. Die onderwyser behoort ook oor die vaardigheid te beskik om die angs- en vreesboodskappe wat uit die media na vore kom, vir die leerders te vertolk sodat hulle daardeur gevorm kan word en nie vreesbevange of angstig word nie. Die onderwyser moet dus 'n veilige omgewing vir die leerders skep. Dit behels onder meer dat die portuurgroep van die VIGS-lyer gelei moet word om ook ondersteunend te kan optree (Strategies for Hope 12, 1997:10). Maats kan leerders wat dikwels weens die siektetoestand afwesig is, help met die inhaal van agterstallige skoolwerk.

\subsection{Die vaardigheid om die belange van weeskinders te behartig}

Onderwysers gaan toenemend te doen kry met die probleem van weeskinders in skole (Louw, Edwards \& Orr, 2001:25). Sulke weeskinders het dikwels te doen met psigo-sosiale stres en die finansiële probleme wat gepaard gaan met die versorging van ander gesinslede, begrafniskoste, skoolfooie en skooldrag. Die ekstra las om vir kleiner broers en susters te sorg veroorsaak dat leerders nie in die skool na wense kan presteer nie en dit lei ook by hom of haar tot verlaagde lewensgehalte. Onderwysers moet hulle help om hierdie las te kan dra en ook om die psigo-sosiale probleem van stigmatisering die hoof te kan bied (Mbeki, 2001:32). Sulke leerders mag aan gevoelens van verlies ly, wat weer uitloop op depressie, ondervoeding, gebrek aan gesondheidsorg, gebrek aan skoling, stokkiesdraaiery, misdaad en verdere blootstelling aan MIV/VIGS. Hulle kan ook ly aan gevoelens van verwerping, gebrek aan ouerliefde, stres vanweë die versorging van broers en susters wat liefdeloos grootword en gevoelens van verwerping en skuld ervaar. Hulle word ook blootgestel aan uitbuiting en kan verplig word om deel te word van prostitusie ter wille van oorlewing (Wood, 1994:8). Sulke leerders moet toegerus word met lewens- en veral oorlewingsvaardighede. In 'n sekere sin sal die onderwyser van sulke leerders in loco parentis moet optree; dus as surrogaat-ouers. Die onderwyser as "plaasvervanger-ouer" moet die leerder wat hom of 
haar in hierdie omstandighede bevind, help om die omstandighede te bowe te kom en 'n menswaardige toekoms tegemoet te kan gaan.

\subsection{Die vaardigheid om geslags- en seksopvoeding aan te bied}

Wat geslags- en seksopvoeding betref, moet die onderwyser 'n bydrae probeer maak voordat leerders seksueel aktief begin raak (Edwards \& Van der Merwe, 1999:5). Dit beteken dat reeds op 'n vroeë ouderdom daarmee begin moet word. Ten minste een uit elke vyf kinders tussen die ouderdomme van 12 en 17 het al seksuele ervaring op die ouderdom 12 opgedoen (Mbeki, 2001:23). Dit is noodsaaklik om aan geslagsopvoeding aandag te gee weens die feit dat geslagtelike bewuswording so belangrik in die lewe van 'n jongmens is. Die Joint United Nations Programme on HIV/AIDS het in 1998 aan die lig gebring dat kinders in staat is om veiliger seksuele gedrag aan die dag te lê as hulle oor die nodige inligting, vaardighede en middele beskik. Die onderwyser bevind hom of haar in 'n uitstekende posisie om leerders te lei tot verantwoordelike seksuele gedrag. Hierdie leiding moet egter nie geïsoleerd plaasvind nie, maar wel in die konteks van die bemeestering van alle lewensvaardighede (Greathead, Devenish \& Funnell, 1998:xv). Leerders moet seksualiteit nie slegs verstaan nie, maar ook die plek daarvan in die totaliteit van menswees raaksien. Leerders moet nie 'n afsku in seks kry nie, maar moet die voor- en nadele van seksuele handelinge leer en verstaan. Deur die verskaffing van die nodige inligting kan die leerder die regte besluite neem en ook daarvoor verantwoordelikheid neem. ${ }^{13}$

\subsection{Die vaardigheid om berading te kan doen}

Ook behoort die onderwyser te beskik oor die vermoë om berading te kan doen. Deur beskikbaar te wees vir berading is die onderwyser in staat om die leerders te bemagtig om ingeligte en verantwoordelike besluite te neem, om meer positief te lewe en om die verspreiding van MIV/VIGS te voorkom. Hierdie dienste word

13 Op hierdie punt bestaan daar nogal meningsverskil. Sommige opvoedkundiges gaan van die veronderstelling uit dat die onderwyser slegs waardeverheldering moet doen, en dit aan die leerder moet oorlaat om self oor 'n waarde(sisteem) te besluit. Ander meen dat die onderwyser as opvoeder daadwerklik 'n bepaalde waardesisteem aan die leerder moet voorleef, juis omdat die leerder nog onvolwasse is. Baie opvoeders wat vanuit 'n reformatoriese perspektief werk, is aanhangers van die laasgenoemde benadering (vgl. ook De Klerk, 2000:341 e.v.; Moodley, 2002:73). 
gewoonlik deur professionele beraders verskaf, maar die gewone onderwyser beland dikwels in 'n situasie waarin berading gegee moet word. Om leerders van goeie advies te kan bedien, moet die onderwyser onder meer beskik oor goeie selfkennis, kennis van eie waardes, vooronderstellings en opvattings, moet hom of haar kan weerhou van veroordeling, in staat wees om aktief te luister, om ondersteunende vrae te stel en opmerkings te maak. Ook moet die onderwyser weet om nie verkeerde verbale en nie-verbale boodskappe aan die leerder te stuur nie, in staat wees om praktiese ondersteuning, inligting en raad te gee, om verskillende opsies ten aansien van versorging, voorkoming en ondersteuning aan die hand te doen. Van die onderwyser kan ook verwag word om te weet hoe en wanneer om verskynsels soos skok, depressie, vrees, angs, skuldgevoel, verlies, ontkenning, smart, en selfmoordtendense vir meer gespesialiseerde berading en hantering te verwys (UNAIDS, Technical Update, 1997:5).

\section{Tot welke mate beskik onderwysers wel oor hierdie vaardighede om die uitdagings van MIV/VIGS- opvoeding die hoof te bied?}

Ten einde hierdie vraag te kan beantwoord, is 'n vraelys opgestel en aan 'n groep respondente voorgelê. Omdat die groep beperk was tot 'n steekproef van onderwysers met minstens een jaar onderwyservaring kan die bevindinge van die ondersoek nie tot alle onderwysers veralgemeen word nie. Hierdie groepe ouderdomme wissel van 20 en 60 en is verbonde aan sekondêre skole in die Merebankgebied in die Noord-Durbanse onderwysstreek en die Isipingo-gebied in die Suid-Durbanse streek. Omdat MIV/VIGS so 'n groot probleem in Kwazulu-Natal is ${ }^{14}$, gee dit egter 'n goeie aanduiding van die mate waartoe onderwysers meen dat hulle toegerus is om te voldoen aan die uitdagings van MIV/VIGS-opvoeding.

Afdeling 1 van die vraelys was gerig op die insameling van biografiese inligting, afdeling 2 op die uitdagings van die MIV/VIGSepidemie en -opvoeding, en afdeling 3 op die pedagogiese verhoudinge van die respondente. Afdeling 4 het geleentheid aan die respondente gegee om hulle menings te lug oor die uitdagings wat die MIV/VIGS-epidemie en -opvoeding aan die onderwyser stel.

14 Beskikbare statistiek, gegrond op syfers verkry van voorgeboorteklinieke, dui daarop dat die voorkoms van VIGS wissel van $8,7 \%$ in die Wes-Kaap tot $36,2 \%$ in Kwazulu-Natal (Jongbloed, 2002). 
Die vraelys is opgestel in oorleg met ' $n$ aantal MIV/VIGS-beraders, onderwysers wat hulle toespits op MIV/VIGS-opvoeding, asook ander persone met gevestigde belange by die hantering van MIV/VIGS. ' $n$ Loodsstudie is uitgevoer ten einde die geldigheid en die betroubaarheid van die instrument te verhoog. 'n Verteenwoordigende steekproef van 150 respondente het aan die ondersoek deelgeneem (76 manlik en 74 vroulik).

Die meeste $(47,3 \%)$ van die respondente was tussen die ouderdomme 31 tot 40.15 Verreweg die meeste van die totale groep respondente het geen opleiding in die hantering van MIV/VIGS gehad nie (84,7\%). Die meeste (meer as $96 \%$ ) het ook minder as twee jaar blootstelling aan MIV/VIGS-geïnfekteerdes in die klaskamer gehad. 'n Groot persentasie (86,7\%) van hulle het aangedui dat daar in hulle skole nie spesiale periodes vir MIV/VIGS-opvoeding is nie. Ongeveer $76 \%$ van die respondente het gemeen dat die gewone onderwyser 'n belangrike rol te speel het in die toerusting van die leerders om die impak van MIV/VIGS te verstaan. Slegs ongeveer $15 \%$ het gemeen dat die gewone onderwyser nie 'n rol hierby behoort te speel nie. Byna almal $(89,3 \%)$ het aangedui dat hulle betrokke sou raak by MIV/VIGS-opvoeding as hulle daarvoor opgelei sou word. Verreweg die meeste $(85,3 \%)$ het gemeen dat die skool wel 'n taak ten opsigte van MIV/VIGS-opvoeding het en nie slegs die ouers nie. Ongeveer 90\% het gevoel dat MIV/VIGSopvoeding deel van die normale skoolkurrikulum moes vorm.

Wat die vaardighede ten aansien van MIV/VIGS-opvoeding as sodanig betref, het $87,3 \%$ van die respondente gevoel dat hulle wel in staat was om die leerders te lei tot verantwoordelike besluitneming in die konteks van MIV/VIGS-opvoeding. Baie $(75,3 \%)$ het ook gemaklik gevoel met die gedagte dat hulle seksopvoeding in die raamwerk van hierdie program behoort te kan gee. Die meeste $(80,7 \%)$ het verder gevoel dat leerders wat MIV-positief is, wel in skole opgeneem moes word. Verreweg die meeste $(98,0 \%)$ het gemeen dat onderwysers opleiding in eerstehulp moet ontvang. Hoewel die meeste van die respondente van oordeel was dat die onderwyser en die skool wel 'n taak het ten opsigte van MIV/VIGSopvoeding, het meer as die helfte $(55,3 \%)$ aangedui dat hulle hulself nie opgewasse en dus toegerus vir die taak beskou nie. 'n Kwart van die respondente het hulleself as opgewasse (toegerus) beskou

15 Die ondersoek het 'n omvattende reeks bevindinge opgelewer. Slegs bevindinge wat verband hou met die tema van hierdie artikel word hier weergegee. Inligting oor ander bevindinge en gevolgtrekkings is by die outeurs beskikbaar. 
en die res was onseker. Hierdie bevinding is gesteun deur die bevinding dat ongeveer $56 \%$ van die respondente gevoel het dat hulle leerders nie vertroue in hulle het as dit by MIV/VIGS-opvoeding kom nie. Meer as $38 \%$ was onseker of hulle die vertroue van die leerders in hierdie konteks geniet. Slegs $45,3 \%$ van die respondente het aangedui dat hulle die MIV/VIGS-beleid van die skool toepas, terwyl meer as $20 \%$ aangedui het dat hulle dit nie doen nie en $34 \%$ onseker was hoe hulle moes respondeer op hierdie vraag.

Op grond van hierdie bevindinge kan die konklusie getrek word dat gewone klasonderwysers nie voldoende opgelei is/word in die vaardighede wat nodig is vir die behartiging van MIV/VIGS-opvoeding nie. Onderwysers skyn nie doelgerigte en beplande ingrepe te kan doen wat MIV/VIGS-opvoeding betref nie; hulle ingrepe is hoofsaaklik in die verbygaan, insidenteel. Die ondersoek het ook aan die lig gebring dat daar niks skort met die gesindheid van die respondente nie: hulle was bereid om betrokke te raak by MIV/VIGS-opvoeding en wel in skoolkonteks. Daar is egter 'n klaarblyklike gebrek aan opleiding, vaardighede, en 'n duidelike onsekerheid oor die mate waarin hulle kan of behoort deel te neem aan die amptelike MIV/VIGS-opvoedingsprogram van hulle skool. Daar is ook opvallende onsekerhede oor die toepassing van die beleid vir die hantering van die MIV/VIGS-program in hulle onderskeie skole.

\section{Aanbevelings en slotsom}

Vanuit die perspektief van 'n reformatoriese opvoedingsraamwerk beskou, word aanbeveel dat onderwysers doelgerig soos volg toegerus behoort te word om die uitdagings van MIV/VIGS-opvoeding die hoof te kan bied:

\subsection{Hulle behoort MIV/VIGS-opvoeding as 'n proses van dubbele ontplooiing of ontsluiting te verstaan}

Opvoeding, dus ook MIV/VIGS-opvoeding, is 'n proses van ontvouing, ontplooiing of ontsluiting. Aan die een kant word die potensiaal van die opvoedeling (met name die leerder) ontplooi. Die VIGS-geïnfekteerde het bepaalde potensiaal wat ontplooi moet word en dit moet gedoen word tydens die aantal lewensjare wat hom of haar gegun word, ook in die skool. Selfs die beperkte potensiaal van 'n leerder wat na 'n enkele jaar of twee op skool te sterwe kom, moet ontwikkel word. Die ontwikkeling van hierdie klein bietjie potensiaal voeg waarde toe aan die vaardigheidspoel van die land en sy mense en is belangrik in die diens van God. Ook die 
potensiaal van 'n weeskind wat sy of haar ouers weens VIGS verloor het, moet optimaal ontwikkel word. Die onderwyser mag nie terugsit en toesien dat die kind vasgevang raak in 'n stryd om bestaan en vir die oorlewing van jonger broers en susters nie. Waardevolle potensiaal gaan op hierdie manier verlore. Die onderwyser moet daadwerklike ingrepe in die lewe en bestaan van hierdie kinders maak sodat hulle tot optimale ontplooiing kan kom en waardevolle bydraes in die toekoms kan maak.

Maar omgekeerd behoort ook die skepping vir die leerders, met name die MIV/VIGS-geïnfekteerde, ontplooi te word. Die skepping sit vol moontlikhede wat God daarin geplaas het en dit is die taak van die onderwyser om hierdie potensiaal vir die leerders bloot te lê. Hy moet by hulle nuuskierigheid opwek en hulle opgewonde maak oor alles wat daar in God se skepping vir hulle lê en wag om benut te word. Hulle moet egter ook daarop bedag gemaak word dat siektetoestande en epidemies soos MIV/VIGS, seksueel oordraagbare siektes - siektes wat deur VIGS vererger word (soos tuberkulose en cholera) - in die skepping se gebrokenheid opgesluit is. Elke onderwyser het die taak om die skepping vir die leerders te ontsluit, en wel op so 'n manier dat hulle sowel die potensiaal as die gevare in die skepping sal verstaan. 'n Deel van die ontsluiting van die skepping is ook om die sonde te ontbloot en aan die kaak te stel, insluitende die sonde van byvoorbeeld losbandige seksuele gedrag. Hulle moet ook verstaan dat die mens tans in 'n gebroke toestand lewe, maar dat die volledige herskepping van alle dinge in die toekoms wag.

\subsection{Hulle behoort MIV/VIGS-opvoeding as instaatstelling (bemagtiging) te beskou}

Opvoeding vanuit reformatoriese perspektief sluit ook instaatstelling in. Deur die ingrepe en tussenkoms van elke onderwyser behoort elke leerder in staat gestel te word om as rentmeester of stadhouer van God in die skepping te kan optree. Die mens is nie die magtelose prooi van epidemies soos MIV/VIGS nie, maar moet in staat wees om dit te kan beheers en te oorwin. Die leerders moet dus toegerus (in staat gestel; bemagtig) word om die gevare raak te sien, te vermy, die hoof te bied, en boweal te bestry. Leerders moet dus onder meer aangemoedig word om biochemici, bioloë en medici te word sodat hulle in die toekoms kan help met die soektog na 'n volkome effektiewe anti-retrovirale geneesmiddel. 


\subsection{Hulle behoort MIV/VIGS-opvoeding as dissipelvorming te beskou}

Opvoeding vanuit reformatoriese perspektief is ook dissipelvorming. Dissipelvorming, sê Van Dyk (2000:65), is om die Woord van God te hoor en dit ook te doen. Om te doen wat God in sy Woord beveel, is om Hom te dien as 'n liefdevolle en toegewyde dienskneg. Om God waarlik lief te hê is om Hom en die naaste met oorgawe te dien. Elke onderwyser moet dus toegewyd wees aan die taak van dissipelvorming, met ander woorde om leerders te lei om met toewyding God en hulle naaste te dien. Hierdie diens het twee kante, meen Van Dyk (2000:66). Aan die een kant dui dit op versorging, om met sorg na ' $n$ ander se belange om te sien. In die konteks van MIV/VIGS-opvoeding kom dit neer op die versorging van die VIGSgeïnfekteerde en sy of haar naasbestaandes. Aan die ander kant het diens die bykomende dimensie van heling, versoening en vredeskepping. Die koms van die sonde in hierdie wêreld het gelei tot grootskaalse gebrokenheid. Dissipelskap in die perspektief van die sonde dui dus op pogings om die gebrokenheid te herstel en te bestry. In die konteks van MIV/VIGS-opvoeding dui hierdie faset van dissipelskap op die bestryding van die siektetoestand waar 'n mens dit ook al teëkom - ook in die klaskamer.

\subsection{Hulle behoort MIV/VIGS-opvoeding as modellering (vorming) te beskou}

Ten slotte het opvoeding vanuit reformatoriese perspektief te doen met modellering. Weens die relatiewe onmondigheid en onvolwassenheid van die opvoedeling (met name die leerder) is dit nodig dat die opvoeder (onderwyser, in hierdie geval) die nodige voorlewing van beginsels en waardes moet doen. Die onderwyser moet 'n navolgenswaardige voorbeeld stel. Hoewel die woorde van die onderwyser (oor seksuele gedrag, byvoorbeeld) wek, is dit die voorbeeld van die onderwyser (verantwoordelike gedrag en voorlewing van waardes en norme) wat trek. Die onderwyser moet vanweë die integriteit van sy of haar karakter en persoonlikheid ' $n$ rolmodel vir die leerders word, een wat hulle gewillig en met oorgawe wil naleef.

Hoewel dit in Suid-Afrika, in die nuwe staatkundige bedeling waarin die land, en derhalwe die onderwys, hom sedert 1994 bevind, nie meer moontlik is om aan te dring op MIV/VIGS-opleiding of -toerusting van onderwysers vanuit voorgaande reformatoriese 
opvoedingsperspektief nie, is dit tog wenslik dat onderwysers, ongeag hulle religieuse of lewensbeskoulike oortuiging, kennis sal neem van die feit dat MIV/VIGS-opvoeding vanuit die vermelde vier perspektiewe gedoen kan en moet word:

- die onderwyser moet hom of haar toewy aan die tweevoudige ontplooiingstaak van opvoeding, naamlik van die leerder en van die werklikheid;

- die onderwyser moet die leerder in staat stel (bemagtig) om die gevare van MIV/VIGS te verstaan en te kan bestry;

- die onderwyser moet die leerders toerus om waarlik volgelinge te word, dit wil sê mense wat ander, ook VIGS-geïnfekteerdes, dien, bystaan en liefdevol versorg;

- onderwysers moet altyd daarna streef om navolgenswaardige rolmodelle te wees en voorbeelde te stel, sodat die leerders hulle na hulle onderwysers se voorbeeld kan modelleer (vorm). Onderwysers wat toegerus is met hierdie vaardighede sal die uitdagings van MIV/VIGS-opvoeding effektief die hoof kan bied.

\section{Geraadpleegde bronne}

ACHINEKU, I. \& MAP INTERNATIONAL. 1999. The AIDS crisis in Africa. Our Christian responsibility. Potchefstroom: Institute for Reformational Studies. Study F1:380. Aug.

ANONIEM. 2002. No time to spare as HIV/Aids toll reaches 30-million in Africa. Weekend Post, November 30.

BLOMFIELD, A. 2004. Millions in Africa free of Aids - Kenyan research. Weekend Post, January 10.

BRADSHAW, D. 2003. Premature deaths from AIDS likely to double by 2010 . The Sunday Times, May 18.

CONNOR, S. \& KINGMAN, S. 1988. The search for the virus: the scientific discovery of AIDS and the quest for a cure. London: Penguin.

DE KLERK, J. 2000. Waarde-uitklaring: Trojaanse perd in Suid-Afrikaanse skole? Koers, 65(3):341-356.

DEPARTEMENT VAN ONDERWYS. 1996a. National Policy on HIV/AIDS for learners in public schools. National Education Policy Act 1996 (No. 27 of 1996). Pretoria: Government Printer.

DEPARTEMENT VAN ONDERWYS. 1996b. National Policy on HIV/AIDS for learners and educators in public schools and students and educators in further education and training institutions. Kennisgewing no. 1926. Pretoria: Government Printer.

DE VILLIERS, J. \& Pienaar, A. 2003. "So erg soos apartheid" - staat verbied voorlegging van nevirapien-aanvoorprogram. Die Burger, Aug. 6.

DU TOIT, Z.B. 2002. VIGS kan Eurasië verlam, sê navorser. Rapport, Desember 1.

EDWARDS, D.N. \& VAN DER MERWE, A. 1999. Pilot project on life skills and AIDS. Teachers Resource Guide. Pretoria: Kagiso. 
FERNHOUT, H. 1997. Christian schooling: Telling a world view story. (In Lambert, I. \& Mitchell, S. The crumbling walls of certainty. Sydney: Centre for the study of Australian Christianity. p. 75-98.)

FOWLER, S. 1987. Christian educational distinctives. Potchefstroom: Institute for Reformational Studies.

FOWLER, S., VAN BRUMMELEN, H.W. \& VAN DYK, J. 1990. Christian schooling: Education for freedom. Potchefstroom: Institute for Reformational Studies.

GEORGE, G. 2001. Fact file business. Siyaya! 8, Winter.

GREATHEAD, E., DEVENISH, C. \& FUNNELL, G. 1998. Responsible teenage sexuality. A manual for teachers, youth leaders and health professionals. Pretoria: Van Schaik.

HAFFAJEE, F. 2001. Rare Gems. Siyaya! 8, Winter.

JELLEY, S. 2003. Why it pays to fight HIV/AIDS. Sunday Times Business, July 20.

JONGBLOED, Z. 2002. Onderwys is nog die enigste "entstof" teen vigs. Rapport, November 24.

KRUGER, N. 1998. Facilitating life skills: your survival guide. Pretoria: Amabhuku.

LAMPRECHT, D. 2003. Meer word siek in VSA weens onveilige seks. Die Burger, Julie 31.

LOUW, N. 2003. Oos-Kaap bloei oor afwesiges. Die Burger, April 23.

LOUW, N., EDWARDS, D. \& ORR, J. 2001. HIV and AIDS: care and support of affected and infected learners - a guide for educators. Pretoria: Department of Health.

MBEKI, Z. 2001. Impending catastrophe revisited. An update on HIV/AIDS epidemic in South Africa. Lovelife, 1(12):3-8.

MIDDLETON, J.R. \& WALSH, B.J. 1995. Truth is stranger than it used to be. Downers Grove: InterVarsity.

MKHWANAZI, S. 2003. School right to bar HIV-child - court. The Herald, October 23.

MONARE, M. 2003. All educators to be tested for HIV. The Sunday Times, July 27.

MOODLEY, J. 2002. The challenges facing the HIV/AIDS educator. Umlazi: University of Zululand. (D.Ed. thesis.)

RANK, F. 2004. Aids stats "grossly inaccurate". Weekend Post, January 10.

Rapport. 2002. Fokus op MIV/VIGS. Desember 1.

REPUBLIEK VAN SUID-AFRIKA. 1996. Grondwet van die Republiek van SuidAfrika. Wet no 108 van 1996. Pretoria: Staatsdrukker.

REPUBLIEK VAN SUID-AFRIKA. 1996. Suid-Afrikaanse Skolewet. Wet no 84 van 1996. Pretoria: Staatsdrukker.

REUTERS \& BBC NEWS. 2003. Elke 14 sekondes kry een mens jonger as 25 MIV/Vigs. Die Burger, Oktober 9.

SCHNEIDER, H. 2001. A struggle for symbolic power. Siyaya! 8, Winter.

SOUL CITY: DEPARTMENT OF HEALTH. s.a. (2003?) It affects us all ... know the facts. Pamflet distributed by Soul City: Department of Health. PO Box 1290, Houghton, 2041. South Africa.

STRATEGIES FOR HOPE (12). 1997. A common cause: Young people, sexuality and HIV/AIDS in three African countries. London: Hamlyn House.

TAITZ, L. 2001. From despair to a gleam of hope. The Sunday Times, November 25. 
TURNER, C.F., MILLER, H.G. \& MOSES, L.E. 1989. Sexual behaviour and intravenous drug use. Washington: National Academy.

UNAIDS: TECHNICAL UPDATE. 1997. Counselling and HIV/AIDS. UNAIDS Best Practices Collection. W C, 503:6.

VAN DYK, A. 1999. AIDS care and counselling. Cape Town: Maskew Miller Longman.

VAN DYK, A.C. 1991. AIDS: to care or not to care. Unisa Psychologia, 18(1):47.

VAN DYK, J. 2000. The craft of Christian teaching. Sioux Center: Dordt.

VREY, J.D. 1993. The self-actualizing educand. Pretoria: Universiteit van SuidAfrika.

WILLEMSE, H. 2003. MIV/VIGS-lyers het nou ten minste hoop. Die Burger, Augustus 12.

WOOD, G. 1994. Suffer the little children. Positive Outlook: the Thinking Person's AIDS Awareness Magazine, 6(6):8.

\section{Key concepts:}

education from a reformational perspective empowerment (enabling)

HIV/AIDS education

\section{Sleutelbegrippe:}

bemagtiging (in staatstelling)

MIV/VIGS-opvoeding

opvoeding vanuit reformatoriese denkraamwerk 
